\title{
Kozmogenezis:
}

\section{Szaktudományos és vallási szempontok a világegyetem eredetével összefüggésben}

\author{
Bagyinszki Péter Ágoston OFM ${ }^{\mathrm{a}}$, Mészáros Lukács ${ }^{\mathrm{b}} \&$ Szeiler Zsolt ${ }^{\mathrm{c}}$ \\ ${ }^{a}$ Sapientia Szerzetesi Hittudományi Főiskola, 1052 Budapest, Piarista köz 1. \\ bagyinszki.agoston@sapientia.hu \\ ${ }^{\mathrm{b}}$ Ferences Gimnázium, 2000 Szentendre, Áprily Lajos tér 2. \\ Eötvös Loránd Tudományegyetem, Öslénytani Tanszék, 1117 Budapest, Pázmány Péter sétány 1/C. \\ lgy.meszaros@gmail.com \\ ${ }^{\mathrm{c}}$ Sapientia Szerzetesi Hittudományi Főiskola, 1052 Budapest, Piarista köz 1. \\ Pázmány Péter Katolikus Egyetem, Bölcsészet- és Társadalomtudományi Kar, 2087 Piliscsaba, Egyetem u. 1. \\ zsoltszeiler@yahoo.com
}

Bagyinszki P. Á., Mészáros L. \& Szeiler Zs. (2017): Kozmogenezis: Szaktudományos és vallási szempontok a világegyetem eredetével összefüggésben. Cosmogenesis: Scientific and religious aspects with regards to the origins of the universe. Acta Pintériana, 3, 71-91.

Jelen tanulmányban négy lépésre bontva tárgyaljuk az univerzum keletkezésével összefüggő kérdések közül azokat, amelyeket a természettudományok és a kereszténység párbeszéde szempontjából ma kiemelkedően fontosnak ítélünk. ${ }^{346}$ Első lépésben a világegyetem fogalmának mai problematikája tisztázandó. Második lépésben az evolutív világegyetem standard paradigmájának kell kiemelt figyelmet szentelnünk, a keresztény szempontból releváns filozófiai kérdések tárgyalása felé haladva. ${ }^{347}$ Harmadik lépésben a teremtettség zsidó-keresztény gondolatát, valamint a dinamikus univerzumképünket kell párbeszédbe hoznunk egymással. ${ }^{348}$ Végül a „kozmológiai apória” feloldásának egy lehetséges módjára mutatunk rá Karl Rahner nyomán. ${ }^{349}$ Tárgyalásmódunk elsősorban didaktikus szempontokat követ, amennyiben e tanulmányt majd egy tankönyvi fejezetté

${ }^{346}$ E dolgozat a korábbi általánosabb gondolatmenetünket mélyíti el a világegyetem keletkezésének konkrét összefüggésében. Vö. BAGYINSZKI P. ÁGOSTON - MÉSZÁROS LUKÁCS: Az evolúciós elv és a létezők hierarchiája. Illeszkedik-e egymáshoz a természettudományok evolúciós elve és a létezők hierarchiájának vallástörténeti eszméje?, Sapientiana 9 (2016/1) 1-13; valamint BAGYINSZKI ÁGOSTON - MÉSZÁROS LUKÁCS: Biogenezis. Az élő és élettelen közötti határsáv problémája, Acta Pintériana 2 (2016/2) 39-53.

347 A szerzők külön köszönettel tartoznak Dr. Kádár György fizikusnak, aki időt szánt a szaktudományos részletek pontosítására.

348 Néhány szemléletmódunkat alakító szerző és munka: TótH KÁLMÁN - FREUND TAMÁS - RÓZSA HUBA: Teremtés a tudományban, Szent István Társulat, Budapest, 2011; PAUL HAFFNER: Mystery of Creation, Gracewing, Leominster, 1995; valamint FranÇoIs Euvé, PIETRO RAMELlini, WiLliam R. STOEGER és GIUSEPPE TANZELLA-NiTTI szerteágazó munkái az általunk is vizsgált kérdés interdiszciplináris megközelítéséhez. Átfogóbb tudományelméleti szemléletformáláshoz lásd MAX SECKLER: A teológia a tudományok között, in Bagyinszki Ágoston (szerk.): A hitvallástól a teológiai megalapozásig. Szöveggyüjtemény a teológiai ismeretelmélet tanulmányozásához, Sensus Fidei Fidelium 3., L'Harmattan Sapientia Szerzetesi Hittudományi Főiskola, Budapest, 2014, 164-176.

349 Vö. PAul OVerhage - KARL RAHNer: Das Problem der Hominisation. Über den biologischen Ursprung des Menschen, Freiburg, Herder, 1961. Ez a klasszikus tanulmány véleményünk szerint megfelelő alapozást nyújt az e cikkben tárgyalt problematika filozófiai szempontjának kifejtéséhez. 
fejlesztve, egyetemisták számára szeretnénk érthetővé tenni az interdiszciplináris párbeszéd kapcsolódó témáit.

\section{Megjegyzések az univerzum fogalmát illetően}

\section{a. Kozmológiák: a világegész megragadására irányuló vállalkozások}

A kozmológia kifejezés, amint azt tudománytörténetének fényében megállapíthatjuk, valamilyen módon mindig a világegészre irányuló vállalkozásokat jelölte. Az archaikus kultúrák világképét, gondolkodását, mítoszait vizsgálva azt tapasztalhatjuk, hogy ezekben mindig fellelhető egy olyan leírás, elképzelés, amely valamiképpen a világra mint egészre, illetve egy olyan „teljesség” rendjére, törvényszerüségeire és történetére irányul, amely átfogja a létezőket és amelynek minden létező a részét képezi. Ezeket a mítoszokat naiv kozmológiák elnevezéssel illethetjük. E mitikus kozmológiák funkcióját átveszik, racionalizáltan és demitizáltan továbbviszik a görög, majd a későbbi kozmológiák. E kozmológiák tárgya egyrészt a létezőket átfogó világ mint egész, másrészt az ebben érvényesülő meghatározó törvényszerüségek, szabályok, hatalmak és erők.

A tudománytörténet kozmológiai paradigmáin végigtekintve felvetődik a kérdés: milyen értelemben azonosíthatók különböző történeti korok világegyetemei? A Milton Karl Munitz (19131995) képviselte tudományfilozófiai nézet szerint csak illúzió a folytonosság és az azonosság, és bele kell törődnünk abba, hogy a világegyetem fogalma, amely a kozmológiának mint egy sajátos kulturális-szellemi törekvésnek a történeti önazonosságát adhatná, különböző korok sajátos világfelfogásaira hullik szét. Bernhard Sticker (1906-1977) szerint sem lehet a kozmológia tárgyát a kozmológia fejlődésének adott történeti időszakától elvonatkoztatva megadni. E felfogás nyomán Arisztotelész (i. e. 384-322) vagy Ptolemaiosz (kb. 87-160) számára a kozmológia objektumát illetve a világegyetemet - a Föld-középpontú, véges, az állócsillagok szférájával lezáruló bolygórendszer jelentette, míg Kopernikusz (1473-1543) vagy Kepler (1571-1611) számára az ugyancsak véges, Nap-középpontú Naprendszer. Ugyanígy, ebben az értelmezésben a XIX. század végi kutatók egy részének világegyeteme a Tejútrendszerrel volt azonos, míg a mai kutatók számára a Hubble-törvény által leírt vöröseltolódást mutató galaxisvilággal ekvivalens.

Azonosíthatjuk-e mégis tudományfilozófiai értelemben a különböző kozmológiák világegyetemének referenciáját? Erre a kérdésre - a világegyetem megfelelő fogalmi meghatározását követően - igennel válaszolhatunk.

\section{b. Az univerzum fogalma és a kozmológia tárgya}

Ha a világegyetem fogalmát, mint a természettudományos kozmológiai vizsgálódások tárgyát megragadó fogalmat definiálni szeretnénk, úgy tünik, hogy sajátos nehézségekbe ütközünk. A világegyetem fogalmára vonatkozó kérdés megválaszolása már bizonyos konkrét kozmológiai ismereteket, állításokat, hipotéziseket tételez fel magáról a világegyetemről: arról az objektumról, amelyről még nem tudjuk pontosan, hogy tulajdonképpen mi, és amelyet éppen definiálni szeretnénk.

Mi a világegyetem? A kozmológiai megfigyelések tárgyát képező csillagászati objektumok összességének halmaza? Az ismert és még ismeretlen galaxisokból és kvazárokból összeálló téridőbeli „kozmikus konglomerátum”? Azonos-e a világegyetem a relativisztikus kozmológiában elméletileg leírt expandáló objektummal? Vagy ez az objektum csak része annak, mert a világegyetemet az ebből, és a még végtelen sok hozzá hasonló, további objektumból összeálló nagyobb egész képezi? Nincs-e valamilyen rejtett filozófiai-logikai következetlenség a világegyetem 
halmazelméleti „összes halmaz halmaza” problémára emlékeztető fogalmában? Az itt felvetődő tudományfilozófiai kérdésekről Székely László (1954-) ad értékes áttekintést az Einstein kozmoszától a fölfúvódó világegyetemig ${ }^{350}$ című könyvében. Székely László szerint a „metafizikai” vonatkozást kikapcsolva, a természettudományos kozmológia világegyetemét a „világegész” tér-időbeli aspektusaként definiálhatjuk. A világegész jelenti a létezők összességét mint egészet. Az így meghatározott világegyetem kielégítően vonatkoztatható az empirikus valóságra, hiszen a létezők összességének minden egyes tagja definíciószerüen létezik, s ebből következően létezik azok összessége is. Az „egész” kifejezés pedig arra utal, hogy ennek struktúrájára mint egészre tekintünk, függetlenül attól, hogy ez az összesség összefüggő rendszert alkot-e, vagy részeire hullik szét. ${ }^{351}$

A fogalom-meghatározás pontosításában továbblépve fel kell fedeznünk, hogy a fizikai kozmológia tárgyaként tekintett világegyetem nem azonosítható a létezők összességével. A fizikai kozmológia nem egyszerüen a létezők összességével, hanem a tér- és időbeli létezők összességével áll relációban. Ha tehát a fizikai kozmológia világegyetemét meg szeretnénk különböztetni a metafizikai értelemben vett világegyetemtől, csak a tér- és időbeli létezők összességéről, illetve az ennek megfelelő téridőbeli világegészről szabad beszélnünk. A fizikai kozmológia a világegésznek mint egésznek pusztán csak a fizikai aspektusával foglalkozik. Ezért a fizikai kozmológia világegyetemét a tér- és időbeli világegész fizikai aspektusaként - fizikai világegészként - határozhatjuk meg. Székely László összegző definíciója szerint ,a fizikai kozmológia tudományának objektumát a priori mint a fizikai világegész konkrét tér-időbeli szerkezetét, valamint mint azokat a nagyléptékü kozmikus struktúrákat és objektumokat határozhatjuk meg, amelyek relevánsak ennek a szerkezetnek a szempontjából" ${ }^{352}$ Ez a meghatározás alapot ad nekünk a történelmi és kortárs kozmológiák egységes szemléletéhez.

\section{c. Fizikai és metafizikai vonatkozások a kozmológiában}

A kozmológiára való igény mélyen gyökerezik az emberben. A végességnek, a korlátozottságnak emberi alapélménye indukálja valami magunknál nagyobbnak, teljesebbnek, valami külsőnek az intuitív képzetét, amely végessé tesz, amely korlátoz. Amennyiben az életről és a halálról, az akaratról és a vágyakról, valamint az ezzel konfrontációba kerülő világról van szó, ez az élmény elvezet a halállal, az akarat korlátokba ütközésével, a szándékok célba nem érésével nem jellemezhető transzcendens, kozmikus lény képzetéig, az egyetemes és végtelen Istenség filozófiai fogalmáig. A naiv mítoszokban még nem található meg ez a fogalom, istenségeik azonban a közöttük feltételezett hierarchiával már ebbe az irányba mutatnak. „Amikor létezésünk ezen eredendő élménye a tér- és időbeli dimenzióban jelenik meg számunkra mint tér- és időbeli korlátozottságunk, illetve ebben az erősen redukált aspektusban viszonyulunk hozzá, az időbeni és térbeni, ám az időben és a térben nem korlátozott, időbelileg és térbelileg mindent átfogó egész képzetéig juthatunk el" - állapítja meg Székely László. ${ }^{353}$ A naiv kozmológiákban az előbbi két mozzanat mindegyike fellelhető: egyrészt a teremtő és uralkodó istenségek és a hozzájuk kapcsolódó kozmikus rend képzetében, másrészt a világ térbeli struktúráját és időbeli történetét leíró, illetve elmondó elbeszélésekben. E kezdeti forrásoknak, illetve az intuitív módon így konstituálódó világegyetem-fogalom referenciájának, mint e mitikus leírások referenciájának, egyformán örököse mind a „metafizikai-transzcendens”, mind pedig a „tudományos-evilági” kozmológiai tradíció. „Maga a »tudományos-evilági« (azaz a természettudományos, a fizikai) kozmológia a »metafizikai« kozmológiáktól szeparálódott el,

\footnotetext{
${ }^{350}$ SZÉKELY LÁSZLó: Einstein kozmoszától a fölfúvódó világegyetemig, Filozófiai Figyelö Kiskönyvtára 5., Filozófiaoktatók Továbbképző és Információs Központja - ELTE Bölcsésztudományi Kar, Budapest, 1990.

${ }^{351}$ Vö. uo. 122.

352 Uo. 125.

353 Uo. 117.
} 
mégpedig oly módon, hogy differencia specifikájává egyik oldalról a tér-időbeli egész »kutatása«, a tér-időbeli egész artikulálása, másik oldalról pedig ennek végrehajtásában a természettudományos kutatás hagyományos módszerének alkalmazása vált." ${ }^{\text {354 }}$

Figyelemre méltó, hogy a metafizikai és természettudományos kozmológia nem csak eredetüket tekintve vannak bensőséges kapcsolatban egymással! Az utóbbi persze megpróbált leválni, szeparálódni „gyanús” rokonától, ám ez a rokonság ennek ellenére újra meg újra előbukkan. Amikor például Stephen Hawking (1942-) a természettudományos kozmológiára gondolva arról ír, hogy szeretné tudni, miért pont olyan a világ, amilyen, s miért létezik egyáltalán, vagy a keleti filozófiák és az általa javasolt kozmológiai eszmék rokonításával kacérkodik, ez éppen azt bizonyítja, hogy a legszigorúbban természettudományos, a legszigorúbban racionalista kozmológiai elméletalkotó tevékenységben is ott munkálkodik valamiféle abszolútumra törekvés. ${ }^{355}$ Peter Atkins (1940-) Teremtés címü klasszikus könyve a legjobb példa arra, hogy az a népszerüsített természettudományos kozmológia, amely a világ keletkezésével kapcsolatos, hagyományosan vallási tárgyú (metafizikai) kérdések tudományos újratárgyalására vállalkozik, hogyan válhat szcientista mítoszképző tényezővé. ${ }^{356} \mathrm{Az}$ ilyen típusú irodalom sikere - Székely László megállapítása szerint - éppen mítoszpótló voltával magyarázható. ${ }^{357}$ Hawking és Atkins, valamint több más szerző „metatudománya” a határsértés hibáját követi el, hiszen a természettudományos kozmológiát éppen az specifikálja, hogy szigorúan a világegész tér- és időbeli aspektusára irányul, szemben a metafizikai megközelítésmóddal, amelyet nemcsak a tér- és időbeli vonatkozások foglakoztatnak, hanem jellegzetesen egyetemes kozmológiai törvények és világszabályok, valamint a „transzcendens” mozzanatok iránt érdeklődik.

\section{A fizikai kozmológia standard paradigmája}

\section{a. A standard paradigma megjelenése}

A természettudományos kozmológia XX. századi paradigmaváltása Einstein 1917-es kozmológiai dolgozatával kezdődött. Először fogalmazódott meg természettudományos szempontból legitim formában az a lehetőség, hogy a világegyetem térstruktúráját nem-eukleidészi geometriájú, véges, de határtalan modell írja le. A modern természettudományos kozmológiai paradigma kialakulásának következő lépései - az expandáló modellek megjelenése, a Big-Bang hipotézis, és legújabban a fölfúvódó világegyetem elmélete - már az Einstein által megteremtett új fogalmi-nyelvi keretben történtek meg.

A standard paradigmával kapcsolatban az 1980-as évek elején Jakov Boriszovics Zeldovics (19141987) elmondhatta: „a forró univerzum immár olyan realitásnak tekintendő, mint a bolygók kopernikuszi rendszere". ${ }^{358}$ Ez a magabiztosság az elmélet keretét adó általános relativitáselmélet sokszoros kísérleti visszaigazoltságán, vagyis a keret szilárdságán, és konkrétan a megoldásként

\footnotetext{
354 Uo. 117.

355 Vö. STEPHEN HAWKING: Az idő rövid története, Akkord, Budapest, 2010. (ford. Molnár István - Egri Győző); STEPHEN HAWKING: A világegyetem dióhéjban, Akkord, Budapest, 2011. (ford. Both Előd)

356 PETER WiLliams ATKINS: Teremtés, Gondolat, Budapest, 1987. (ford. Kálmán Á. György)

357 Vö. SZÉKELY LÁSZLó: Einstein kozmoszától a fölfúvódó világegyetemig, 119.

358 A fizikai Nobel-díjas kozmológus, Steven Weinberg „Az első három perc” című könyvének (Gondolat, Budapest, 1982) 53, 109, 114, 123 oldalain hivatkozik kollégájának, Zeldovicsnak az eredményeire. A magyar kiadás fülszövege kiemeli Zeldovics fent idézett szavait. A standard modell bemutatásakor itt elsősorban Weinberg klasszikus, népszerüsítő tárgyalásmódjára támaszkodunk. Fizikus lektorunk álláspontja szerint jelen gondolatmenetünk szempontjából nem szükséges kitérnünk a mai vitákban szereplö bonyolult részletkérdésekre.
} 
körvonalazott kozmológiai világmodell következményeinek a megfigyelésekkel való megegyezőségén nyugszik. A legfontosabb kozmológiai múltról árulkodó nyomok a következők: a galaxisok távolsággal arányos vöröseltolódása; izotróp mikrohullámú háttérsugárzás jelenléte és hőmérséklete; a galaxisok nagyléptékủ eloszlása (homogenitás és „falak”); valamint az intersztelláris gázban található kb. 25\% hélium nem származhatott egyedül a csillagok belsejében lezajló fúziókból. Úgy tünik, hogy ezek a „bizonyítékok” háttérbe szorítanak néhány sokat vitatott probléma okozta nehézséget (pl. a „sötét anyag probléma”, a neutrínóháttér kérdése, a „fekete lyukak” kérdése).

A kozmológiai standard paradigma elsősorban a gravitációs kölcsönhatást, ezt az általános relativitáselméletben alapvető jelenséget tekinti a kozmosz szerkezetét és történetét meghatározó tényezőnek, de tekintetbe kell vennie az elemi részecskék kvantumfizikai standard modelljében szereplő nukleáris és elektromágneses kölcsönhatásokat is - különösen a Nagy Bumm utáni rövid időszakban.

A továbbiakban először áttekintjük a világegyetem struktúráját, majd lehetőség szerint tömören összefoglaljuk azt a krónikát, ami a mai struktúra múltját jelenti.

\section{b. A világunk struktúrája}

A Föld, amelyen élünk, egy átlagosan 6.371 km sugarú, jó közelítéssel forgási ellipszoid alakú bolygó. Felszínét egy 50-100 km vastagságú szilárd kőzetburok, a litoszféra borítja, amely alatt a nagy nyomás és a magas hőmérséklet miatt képlékeny anyag található. A bolygó - föként nikkelből és vasból álló - legbelső magja ismét szilárd halmazállapotú. A litoszféra fölött helyezkedik el a folyékony halmazállapotú vízburok (hidroszféra) és a gázokból álló légkör (atmoszféra). Földünk a Naprendszernek a központi csillagtól számított harmadik bolygója.

Naprendszeren a világür azon tartományát értjük, amelyben a Nap gravitációs tere a domináns. Ez a tér egy kb. 2 fényév sugarú gömb, amelynek középpontjában a Nap helyezkedik el. Ennek a csillagnak a tömege 750-szer nagyobb a Naprendszer többi égitestjének ( 8 bolygó és azok mintegy 60 holdja, a Plutoval együtt 5 törpebolygó, kb. 100.000 kisbolygó, üstökösök, meteorok, bolygóközi anyag) együttes tömegénél. Az anyag 99\%-a a Naprendszer szimmetriasíkja közelében koncentrálódik. A bolygók, az üstökösök és a meteorok a Nap körül, Kepler törvényeinek megfelelően, jellemzően közel azonos síkban és egy irányban keringenek. A holdak a bolygók körül néhány kivételtôl eltekintve - szintén ugyanebben az irányban keringenek. A Vénusz és az Uránusz kivételével ugyanilyen irányú a bolygók forgása is. A nagybolygók két világosan elkülönülő csoportot alkotnak. Az első csoportba a Föld-típusú vagy belső bolygók (Merkúr, Vénusz, Föld, Mars) tartoznak. Kis tömegük relatíve nagy sürüséggel párosul, felépítésükben a nehéz elemeknek van döntő szerepe. A második csoport tagjait Jupiter-típusú, külső- és óriásbolygóknak egyaránt nevezik. Kis sủrüségúek, de nagy tömegúek, a könnyü elemek fordulnak elő bennük nagy gyakorisággal.

Napunk a bolygórendszerével együtt egy nagyobb rendszernek, a Tejútrendszernek a tagja. A Tejútrendszer oldalnézetben két, peremével összeillesztett tányérhoz hasonlít, felülnézetben két spirálisan föltekeredő karból áll. Átmérője kb. 100.000 fényév, legnagyobb vastagsága kb. 15.000 fényév. A Tejútrendszer középpontját egy kb. 100 millió naptömegnyi szupercsillag alkotja. Ekörül elsősorban a spirális karokba rendeződve - helyezkedik el kb. 10 milliárd csillag, és a Tejútrendszer össztömegének kb. 5\%-át kitevő diffúz csillagközi anyag. A Tejútrendszerhez tartozik még a középpontot gömbszimmetrikusan körülvevő csillagokból és csillaghalmazokból álló, kb. 150 ezer fényév átmérỏjü, ritka „galaktikus haló”. Napunk az egyik spirális karban, a centrumtól kb. 25 ezer fényév távolságra helyezkedik el. A Tejútrendszer a szimmetriasíkjára merőleges tengely körül 
forgómozgást végez. Ebből kifolyólag Napunk $250 \mathrm{~km} / \mathrm{s}$ sebességgel mozog, és 250 millió év alatt tesz meg egy teljes kört a centrum körül.

A Tejútrendszer a galaxisok egyike a Világegyetemben. Jelenlegi müszereinkkel kb. 10 milliárd fényév sugarú tartományt láthatunk be. Ezt a tartományt metagalaxisnak hívjuk, ami természetesen kisebb, mint a csillagászati értelemben vett világmindenség, más néven univerzum. A metagalaxisunkban több mint 1 milliárd, a mi Tejútrendszerünkhöz hasonló, úgynevezett extragalaxist figyelhetünk meg. Ezek nem mind hasonlítanak a mi galaxisunkra: a spirális formán kívül megfigyelhetők még elliptikus, horgas és szabálytalan alakú extragalaxisok. Az extragalaxisok egy része nagyobb rendszerekbe tömörül, ezek a galaxishalmazok.

Nincs biztos tudásunk arról, hogy mi lehet a metagalaxison túl. A leglogikusabbnak az a feltevés tủnik, hogy - legalábbis egy darabig - az eddig megismert szerkezetü világegyetem folytatódik ott is, és természetesen a világegyetem más tartományaiban is további „metagalaxisokat” feltételezhetünk. Teoretikus érvek alapján próbálhatunk (némileg elkerülhetetlenül bizonytalan) képet alkotni arról, hogy térben (és időben) határos-e az univerzum vagy sem, és hogy a „látóhatárunkon túl” milyen világ van.

\section{c. Az univerzum időbelisége a standard paradigma szerint elbeszélve}

Az extragalaxisok távolodásának tényéből arra következtethetünk, hogy a világegyetem anyaga valamikor igen kis térrészben és igen nagy sürüségü állapotban volt. A számítások szerint ez a szupersürü állapot mintegy 15 milliárd évvel ezelött állt fenn. Ilyen sürüségi viszonyok között nem ismerjük az anyag viselkedését. Ennek az állapotnak az egyediségét úgy próbáljuk kifejezésre juttatni, hogy egy bizonyos „ősrobbanásról” (Big Bang) beszélünk, amely a tágulási folyamat indulási fázisát nevezi meg. A csökkenő sürüségű anyag gyökeres változásokon ment át. Döntő események játszódtak le az első másodpercben. A kezdetek kronológiáját a modern fizika elvi okokból csak a 10^(-43)-dik másodpercig („Planck-idő”) tudja hipotetikusan rekonstruálni. Steven Weinberg (1933-) így ír a kezdetekről: ,,amit mi ma meg tudunk tenni a matematikában, azt a korai univerzumban ténylegesen a forróság valósította meg. A fizikai jelenségek akkor közvetlenül is kifejezték a természet lényegi egyszerüségét. Sajnos nem volt jelen senki, hogy láthassa ezt". ${ }^{359}$ Idővel fokozatosan megjelentek a mai elemi részecskék; kb. 300.000 évvel az ősrobbanás után a fotonok leváltak az anyagról: ekkor már a sugárzás uralta korszakban vagyunk. Az első másodpercet követő egy millió év múltán az univerzum hőmérséklete 3.000 Kelvinre csökkent, amikor is a protonok képessé váltak az elektronok befogására: az eddig ionizált gázból semleges hidrogén jött létre. Az egységes gázanyag először nagyobb, majd kisebb „felhőkké” csomósodott. Az előbbiekből a galaxishalmazok, az utóbbiakból a galaxisok jöttek létre (kb. egymilliárd évvel vagyunk az ősrobbanás után). A galaxisok eredetileg gömb alakú gáztömegek voltak, majd összesürüsödve megindult bennük a csillagképződés (három milliárd évvel az első másodperc után vagyunk), amely folyamat még ma sem ért véget.

A Nap és a Naprendszer többi objektuma valószínűleg a csillagközi anyag ugyanazon felhőjéből, egyszerre alakult ki. A Tejútrendszeren szabályos időközönként körkörösen „végigsöprő” sủrűsödési hullám lehet ennek a sürüsödési folyamatnak a magyarázata. A Naprendszer jelenlegi méretének megfelelő teret tehát egy, a Tejútrendszer egyenlőtlen forgása következtében eleve forgó gázfelhő töltötte ki. A gázfelhő a saját gravitációs hatása miatt összehúzódott. Az összehúzódó tömeg forgása gyorsult, és alakja a forgástengely irányában belapult. Az egyre gyorsabban forgó és belapuló gáztömeg egyenlítője mentén a centrifugális erő következtében egy gyürü vált le. A levált gyürü helyére belülről melegebb gáz áramlott, a kihülés és ezzel együtt az összehúzódás felgyorsult, majd

\footnotetext{
359 STEVEn WeINBERG: Az első három perc, Gondolat, Budapest, 1982, 129. (ford. Gajzágó Éva)
} 
újabb gyürü vált le. Az ily módon sorozatosan levált gyürükből alakultak ki a bolygók. A kifelé áramló gázgyürükkel együtt az ősi Napból kijutó nehezebb, szilárd halmazállapotú anyagszemcsék a csillag közelében összetapadtak és nagyobb testeket képeztek. Így a gáz már nem tudta továbbragadni őket a Nap közeléből: ezért keringenek Föld-típusú bolygók a belső pályákon. A bolygópályákon mozgó, összetapadt anyagtömegek folyamatos ütközései és további összetapadása révén jöttek létre maguk a bolygók. A messzebbre sodródó gázokból hasonló módon alakultak ki a Jupiter-típusú bolygók.

A Föld tehát, mintegy 4,6 milliárd éve, a Nap körül keringő szilárd, kozmikus testek ütközése során keletkezett, és az ütközések energiája, valamint saját gravitációs hatása miatt izzó állapotba került. A képlékeny anyagban gravitációs átrendeződés indult meg, így jött létre bolygónk mai gömbhéjas szerkezete. Az izzó állapot és a gravitációs erő, valamint a tengely körüli forgás centrifugális hatása tette lehetővé a ma ismert „geoid” alak kialakulását. A Föld legkülső rétege a hideg világürbe szétsugárzó hőveszteség nyomán szilárdult meg, majd a már szilárd felszínt övező gázokból a további lehülés során kicsapódott a világóceánokat alkotó víz. Az ősrobbanást követően kb. 12 milliárd évvel az univerzumnak ezen a bolygóján, egyelöre mikroszkopikus formában, de megjelenik az élet...

\section{d. Megjegyzések a standard paradigmával összefüggésben}

Nem szabad szem elől tévesztenünk, hogy a „standard paradigma” tulajdonképpen egy egész elméletcsoportot fog össze. A legegyszerübb eltérések abból származnak, hogy mekkorának becsülik az univerzum átlagos tömegsürüségét. Ennek függvényében ugyanis eltérő lesz az univerzum sorsa és végállapota. Ha a kritikus sürüség alatt vagyunk, akkor a tágulás ugyan minduntalan lassul a gravitáció miatt, de egyre kevésbé, és a végtelenségig folytatódik (ez a kozmikus „kihülés” forgatókönyve). Ha a tömegsürüség épp a kritikus értékü, akkor a tágulás aszimptotikusan lassul és a végtelenül távoli jövőben „megáll”. Ha azonban a kritikus tömegsűrüség fölött vagyunk, akkor az univerzum tágulása véges időn belül megáll, és mivel ekkor véges méretủ az univerzum, a gravitáció tovább müködve elindítja az összehúzódást, ami maga után vonja a tágulási folyamat inverz eseménysorát. A Nagy Bumm adta kezdet így a Nagy Reccs adta végben zárul. Az utóbbi változat sokak számára azért vonzó, mert egy oszcilláló világegyetem lehetőségét engedi meg, ahol „,világkorszakonként” Nagy Bummok és Nagy Reccsek váltják egymást. Ebben az elgondolásban visszatér a világ - időben végtelen, ciklusokba szervezett - mitikus képzetének a mintája. Abban már erősen eltérnek a kozmológusok nézetei, hogy milyen kapcsolat áll fenn két egymás utáni ciklus között. Termodinamikai megfontolások alapján egyesek feltételezik, hogy az entrópia növekedése ekkor is fennáll, ezért az egymást követő ciklusok amplitúdói egy csillapodási folyamatban egyre kisebbek lesznek, míg végül megszünik az oszcilláció. Így ebben az esetben - időben - mégis véges univerzumot kapunk. Mások véleménye szerint azonban két ciklus között nincs semmiféle kauzális kapcsolat, így az sem írható elö, hogy csillapodás jöjjön létre. Egy további variáció, ami az elméleti modellt számottevően módosítja, az inflációs elmélet. Ennek lényege az, hogy az univerzum egy korai szakaszában hirtelen „felfúvódott”, térbeli méretei hirtelen változáson mentek át. Ez a folyamat lényegét nem érinti, de bizonyos elméleti kérdésekre jobb választ kínál. A különböző forgatókönyvek valószínűsủgét tehát az univerzum átlagos tömegsürűségének a csillagászati eszközökkel mért értéke és a mérés hibahatára alapján határozhatjuk meg. Mai álláspont? A Nagy Bummon alapuló kozmológiák kialakulásáról valamint a tudománytörténeti jelentőségü rivális elméletekről - jó áttekintést nyújt John Barrow $A$ világegyetem születése címü klasszikus müve. ${ }^{360}$

\footnotetext{
360 JOHN D. BARROw: A világegyetem születése, Kulturtrade, Budapest, 1994. (ford. Both Előd)
} 
Általánosságban minden kozmológiai modellről elmondhatjuk, hogy a fejlődés iránya az, hogy igyekeznek olyan elméletet alkotni, amely kombinálja a relativitáselméletet és a kvantummechanikát. E kísérlet idáig sikertelen, bár vannak elképzelések, hogyan is kell kinéznie egy ilyen elméletnek. Az optimizmus alapja az, hogy az erős, gyenge és elektromos kölcsönhatást már sikerült egyesíteni, azaz egységes elmélettel leírni. Azonban a kvantumgravitáció megalkotása sokkal nehezebb feladatnak tủnik. Kétségtelen, a fizikai kozmológia az elmúlt évtizedekben komoly eredményeket tudhat magáénak, de mindezzel együtt figyelembeveendő, hogy relatíve még nagyon fiatal tudományágnak számít.

\section{e. Az evolúciós elv kozmológiai alkalmazásának magyarázó ereje}

Az utóbbi száz év kozmológiájának alapvető felismerése, hogy az égitestek - galaxisok, csillagok és bolygók - nem léteztek mindig. És ugyanígy van ez a végsőnek tekintett részecskék vonatkozásában is. Időben változó-fejlődő geometriában létezik az anyagi világ. A csillagok, köztük a mi Napunk is, valamint a bolygók születnek és elpusztulnak. Nem létezhet örökké a mi Földünk, a rajta lévő élet és az emberiség sem. Ma már tudjuk, hogy a kozmoszban nem lelhetjük föl azt a tökéletes szabályszerüséget, amelyet hajlamosak vagyunk keresni benne. A bolygók és mellékbolygók pályái észrevehetően változnak az idők folyamán, sőt, olykor váratlan és hirtelen változások is bekövetkeznek. Metamorfózisokon megy át maga az anyag szerkezete is, még ha mi úgy látjuk is, hogy lényegében változatlan: a világegyetem evolúciójának gondolatából - ami a standard paradigma lényege - az következik, hogy az anyag összes formái, még a számunkra legalapvetőbbnek látszók is, csak átmenetiek. ${ }^{361}$ Bármilyen objektumot vizsgáljunk is ma, el kell fogadnunk a gondolatot, hogy volt vagy lesz olyan korszak, amikor ez a tárgy hiányzik a világegyetemböl. A dinamikus univerzumképünk időtlennek vélt sajátosságait „fizikai törvényekként” tartjuk számon.

A világegyetem története tehát jórészt különböző struktúrák lassú kialakulásából áll. Ahogy sokmilliárd évvel az ősrobbanást követően, a biológiai fejlődés folyamán, a természetes szelekció következtében egyre bonyolultabb kémiai, majd biológiai alakzatok jelennek meg, ugyanígy egyre szövevényesebbé válik a kozmosz szerkezete is. A folyamatot időrendben a nukleonok (protonok és neutronok) kezdték meg, miután kibontakoztak a „kvarklevesből”. A nukleonok, miután létrejöttek, elkezdtek atommagokká fuzionálni. Alig három perc múlva már 25\%-uk egyesült, majd sokkal később ugyanezek a magok - valamint a megmaradt protonok (amelyek voltaképpen hidrogén atommagok) az elektromágneses kölcsönhatások következtében egyesültek az elektronokkal, és létrehozták a voltaképpeni atomokat, ezeket az új struktúrákat, amelyek megjelenése jelzi az anyag és a sugárzás szétválásának pillanatát. Egymillió év múltán a világegyetem ,átlátszóvá” vált. Ettől kezdve különvált az anyag és a sugárzás evolúciója, majd az elektromágneses erők, de még inkább a gravitáció hatására létrejöttek az egyre nagyobb és egyre bonyolultabb struktúrák: először molekulák, majd porfelhők, azután csillagok, galaxisok, galaxishalmazok stb., végül e rendszereken belül mi és az általunk ismert tárgyak. Ha hierarchikusan mélyebb szintről magasabb szervezettségi szintre lépünk, akkor a minőségileg új tulajdonságok megjelenését emergenciának nevezzük. ${ }^{362}$ Ismereteink szerint a világfolyamatnak alapvető jellegzetessége az emergencia-tulajdonság.

A standard paradigma szerint rekonstruált kb. 15 milliárd éves történet nagy vonalakban képes természettudományos magyarázatot adni a mai világegyetemben megfigyelt struktúrára, a „kozmikus

${ }^{361}$ Az „evolúciós elv” természetével és kritikájával kapcsolatos kérdésekhez lásd BAGYINSZKI P. ÁGOSTON MÉSZÁROS LUKÁCS: Az evolúciós elv és a létezők hierarchiája. Illeszkedik-e egymáshoz a természettudományok evolúciós elve és a létezök hierarchiájának vallástörténeti eszméje?, Sapientiana 9 (2016/1) 4-7, 12-13.

${ }^{362}$ E fogalom filozófiai megalapozásához lásd cikkünk 4. részének b. jelzésủ alfejezetét. 
tájra". Abban van az ereje és a jelentősége, hogy a kozmikus evolúciós folyamatok időmetszeteként hatékonyan értelmezi a jelenünk megfigyeléseit. A modern kozmológia továbbá azt is megsejteti velünk, hogy a kozmosznak különböző arcai vannak. Csak valamennyi komplementáris leírás összessége ábrázolja a (legtágabb értelemben vett) természet osztatlan valóságát.

\section{Kapcsolatok a modern univerzumkép és a teremtés eszméje között}

\section{a. A modern kozmológia és a keresztény teológia a téridőről}

A standard paradigma ideológiai-világnézeti kiértékelése nem csak a keresztény teológia perspektívájából történt meg, de mi most erre fordítjuk figyelmünket. Más ideológiai csoportosulások standard paradigmára vonatkozó kritikáiról vagy szimpátiáiról tanulságokkal szolgáló áttekintést ad Székely László korábban már idézett műve. ${ }^{363}$

A modern kozmológia és a kortárs keresztény teológia kapcsolódási pontjainak egy részét a tér és az idő végességéről-végtelenségéről, illetve határoltságáról-határolatlanságáról alkotott elképzelések köré csoportosíthatjuk. Először erről a témakörről próbálunk áttekintést adni.

A térbeliséget illetően: a standard paradigma a határtalan, de véges térbeliség eszméjét hozta újdonságként a tudománytörténetbe. Korábban a teológiai gondolkodás találkozott az antik világkép véges és határos térszerkezetével, a kora újkorban pedig a végtelen és határtalan térbeliség eszméjével. A teológiai gondolkodás számára egyik térstruktúra sem jelentett komoly problémát. Különösen figyelemre méltó ez a térbeli végtelenség esetében, amely Giordano Brunótól kezdődően nemcsak, hogy nem bizonyult kényelmetlennek a teológiai gondolkodás számára, hanem egyre gyakrabban szerepelt Isten mellett szóló érvként, vagy a világegyetem Istentől leszármaztatott és Istenhez egyedül méltó tulajdonságaként.

Sokkal differenciáltabb és összetettebb probléma a világegyetem időbeli kezdetének - azaz a világegyetem múltbéli határoltságának, a Nagy Bummnak - a keresztény teológiával való kapcsolata. A keresztény teremtéstan számára nem szükségképpen kell véges múltbeliséggel rendelkeznie az univerzumnak. Aquinói Szent Tamás A világ örökkévalóságáról (De Aeternitate Mundi) ${ }^{364}$ írott könyvében erőteljesen érvel amellett, hogy adott esetben a világ létezhetett volna öröktől fogva is a maga teremtettségében. Mégis, a keresztény hagyomány fő vonala jellemzően a világ múltjának időbeli határoltságával szimpatizált. Ezt sem szabad azonban félreértenünk, mert Szent Ágoston Vallomások (Confessiones) ${ }^{365}$ című mủvében található (minden nemzedék által olvasott) intelme szüntelen ébren tartotta az idő (és tér) teremtettségének eszméjét. Tudták tehát, hogy ha a világ véges korú, mégsem „időben” keletkezett. Nagyon fontos, hogy a keresztény gondolkodás e meghatározó áramlatának peremjelenségeiként helyezzük el a régi és újabb kreacionista teremtésteológiákat. ${ }^{366}$ Érdemes még megemlítenünk, hogy a kortárs kozmológiában a standard paradigmához kapcsolódóan bukkant fel az az elgondolás, hogy a világegyetem esetleg időben határolatlanul véges múltbelisége eltüntetheti az időbeli szingularitás természettudományos-filozófiai-metafizikai problematikáját. Ez

363 SZÉKELY LÁSZLÓ: Einstein kozmoszától a fölfúvódó világegyetemig; valamint lásd még SZÉKELY LÁSZLÓ: Az emberarcú kozmosz. Az antropikus kozmológiai elv, Áron, Budapest, 1997.

364 AQuinói SzEnT TAMÁs: A világ örökkévalóságáról, Jószöveg Mühely Kiadó, Budapest, 1998. (ford. Borbély Gábor)

365 SZENT ÁGOSTON: Vallomások, Gondolat, Budapest, 1987, Tizenegyedik könyv, VI, XI-XXXI. (ford. Városi István)

366 Vö. BAGYinsZKi P. ÁGOSTON - MÉSZÁROS LUKÁCS: Az evolúciós elv és a létezők hierarchiája. Illeszkedik-e egymáshoz a természettudományok evolúciós elve és a létezők hierarchiájának vallástörténeti eszméje?, Sapientiana 9 (2016/1) 1-13, lásd különösen 2-4. 
az eszme még nem kapott kellő filozófiai figyelmet, de talán a szaktudományos súlya sem elegendő egyelöre a komolyan vételéhez.

A múltbeli szingularitásból evolváló univerzum eszméje tehát - mint meghatározó kozmológiai gondolkodási minta - időben (legalább a múltunk felől) határolt és véges, térben határtalan és véges univerzumképet feltételez. A szingularitás felveti a többi között a természeti törvények eredetének és az univerzális állandók ,finomhangoltságának” problémáját. A keresztény gondolkodás számára nagy a kísértés, hogy kreacionista módon gondolja el a szingularitásban kezdődő világ teremtő Istenhez füződő kapcsolatát. Filozófiai szempontból ez mégis hiba lenne! ${ }^{367}$ Ezen a ponton a „teológiai fizikalizmus" hibájába esnénk, ${ }^{368}$ ha engednénk ennek a kísértésnek, a szemléletmód minden következményét a nyakunkba véve. A meghatározó keresztény filozófiai hagyománnyal együtt a komplementaritás koncepcióját tartjuk követendőnek, ${ }^{369}$ mégpedig következetes módon, a standard modell $\mathrm{t}=0$ időpontjában is, mint ahogy később bármikor.

\section{b. A modern kozmológia és a keresztény teológia a világ rendezettségéről}

Miután áttekintettük a modern kozmológia és a teológia kortárs dialógusának a téridő szerkezetéhez kapcsolódó mozzanatait, fordítsuk figyelmünket a dialógus azon kérdéseire, amelyek az univerzumban talált statikus és dinamikus rendezettséghez kapcsolódnak.

A természettudomány és a teológia dialógusában Isten világegyetemmel fennálló konkrét kapcsolata, annak elgondolhatósága az elsődleges kérdés (a természettudomány oldaláról természetesen Isten léte is kérdéses lehet). A keresztény filozófiában komoly hagyománya van e kapcsolat pusztán emberi gondolkodásra alapozott vizsgálatának. Isten léte intellektuális beláthatóságának problémakörét istenérvek címszó alatt szokták megvizsgálni. A témáról most csak nagyon érintőlegesen, az univerzum teremtettségének a filozófiához legszorosabban kapcsolódó néhány vonatkozásában lesz szó. Először a kontingencia-argumentumot, majd az ún. designargumentumot tekintjük át a fizikai kozmológia összefüggésében. Mindkét argumentumtípusnak létezik statikus és dinamikus jellegü formája. Az első esetben (kontingencia) egy létező puszta létének a ténye jelenti a statikus aspektust, a vele kapcsolatos időbeli változásoknak a ténye pedig a dinamikus aspektust, amiből a gondolatmenet elindul. A második esetben (design) a szabályosság tapasztalata a statikus, az időbeli célosság benyomása pedig a dinamikus érvelés kiindulópontja. A ma meghatározó keresztény hagyomány szerint az istenérvek logikailag nem kényszerítő erejű gondolatmenetek, hanem olyan érvek, melyek világunk megfigyelhető adottságaiból kiindulva plauzibilissé, racionálissá teszik Isten létezésének elfogadását. Sok ilyen gondolatmenetet kidolgoztak a sokféle lehetséges megfigyelésnek megfelelően - ezek érvényességéről vita folyik. Nekünk most csak a fenti két csoporttal kell foglalkoznunk ahhoz, hogy megértsük a teremtés filozófiájának bizonyos kulcspontjait.

Az általunk vizsgált két csoport gondolatmenetei - Brian Davies (1951-) filozófus megfigyelése szerint - a következő egyszerü minta szerint épülnek fel:

„elöször felhívják a figyelmet a dolgok valamely átfogó jellegzetességére, amelyet tapasztalatból ismerünk. Ezután azt állítják, hogy eme jellegzetességek

${ }^{367}$ Lásd ehhez jelen cikkünk 4. fejezetét, valamint vö. BAGYINSZKI ÁGOSTON - MÉSZÁROS LUKÁCs: Biogenezis. Az élö és élettelen közötti határsáv problémája, Acta Pintériana 2 (2016/2) 39-53, különösen 49-51.

368 Vö. BAgYinszKi P. ÁGOSTON: Az üdvtörténet a végjáték felől nézve, in Hetesi Zsolt - Teres Ágoston (szerk.): Vallás és tudomány, Manréza Szimpózium 2004/Dobogókő, Magyar Jezsuita Rendtartomány ELTE Csillagászati Tanszék, Budapest, 2005, 1-19, különösen 5-6.

369 Uo., valamint v.ö. BAGYINSZKI P. ÁGOSTON - MÉSZÁROS LUKÁCS: Az evolúciós elv és a létezők hierarchiája. Illeszkedik-e egymáshoz a természettudományok evolúciós elve és a létezők hierarchiájának vallástörténeti eszméje?, Sapientiana 9 (2016/1) 1-13, lásd különösen 12. 
egyike sem vezethetö vissza a szokványos fizikai okokra, ennélfogva a közvetlen magyarázatnál magasabb szintü magyarázatot kell keresnünk”.

Ezt más formában úgy fogalmazhatjuk meg, hogy ezen gondolatmenetek szerint „a tapasztalható valósággal kapcsolatban feltett kérdéseink újabb kérdéseket vetnek fel, az ezekre adható válaszok viszont már olyasmire utalnak, ami csak tapasztalaton túlinak gondolható el ${ }^{\text {370. }}$.

Az ilyen filozófiai gondolatmenetek mindig „kognitív optimista” beállítottságot feltételeznek, vagyis nem fogadják el azt a valóság abszurditásával egyenértékű (de gyakorlatilag lehetséges) világnézeti opciót, hogy ,a világ egyszerüen a puszta és érthetetlen végső tény”.

A kontingencia-argumentum szerint észre kell vennünk, hogy az egyes dolgok lehetnének másképp is, mint ahogy vannak, illetve létük tagadásával sem foglal magában ellentmondást. Ez a statikus kiindulópont. A dinamikus kiindulópont a világban tapasztalható szüntelen változási folyamatra hívja fel a figyelmünket, ami ismét csak a dolgok „épp így létének” esetlegességére mutat rá. A kontingencia-argumentum lényegét Peter Geach (1916-2013) nyomán így foglalhatjuk össze:

„Ha a világot tárgynak vesszük, akkor újfent természetes lesz felvetni az okára irányuló kérdést, amelyet részeivel kapcsolatban indokolt feltenni. Ha rendelkezik idöbeli kezdettel, akkor mi hozta létre? Ha nem, mi örzi meg a pusztulástól, miközben egyes részei elpusztulnak? És mi tartja fenn a benne vagy rajta lejátszódó folyamatokat?",371

Ehhez kapcsolódva jegyzi meg Brian Davies:

„A világegyetem anyagának folyamatos fennmaradása, vagyis az a tény, hogy világunk megszakítás nélkül létezik, nem magától értetödö. Önellentmondáshoz vezet az az állitás, hogy az univerzum természeténél fogva marad fenn, mivel éppenséggel léteznie kell ahhoz, hogy természete fennmaradjon vagy müködjék. A világ természete tehát feltételezi a világ létezését." ${ }^{772}$

A gondolatmenet így érkezik el egy létet adni képes lény állításához.

A design-argumentum gondolatmenete a világ statikus rendjét és a dinamizmusában érvényesülő „célos jellegét” mint elsődleges emberi tapasztalatot tekinti kiindulópontjának. A kozmológia összefüggésében a természettörvények meglétére, ,jólmegkomponáltságára”, az egyetemes fizikai állandók „finomhangoltságára” alapozhat egy ilyen típusú gondolatmenet. Minderre a világfolyamat máig ismert, közel 15 milliárd éves szakasza látszik garanciát szolgáltatni. A design-argumentum lényege az, hogy értelmet keres az értelmünk által megcsodált tények mögött. ${ }^{373}$

Összefoglalva, arról van tehát szó, hogy a filozófiai gondolkodás az univerzum Istenhez rendeltségére utaló jeleket vél felfedezni a természettudományok által föltárt univerzumképünkben. Ez fontos mozzanat a teremtettség filozófiai értelmezése szempontjából. A vulgáris vallási gondolkodásban - a szemléletességnek engedve - az istenérvek gyakran a teológiai fizikalizmus hibájába esve fogalmazódtak meg, valójában azonban a keresztény gondolkodás autentikus képviselői mindig nyitva hagyták e gondolatmeneteket a komplementer szemlélet irányába. Az istenérveket ezért

\footnotetext{
${ }^{370}$ Mindkét idézethez lásd BRIAN DAVIES: Bevezetés a vallásfilozófiába, Kossuth, Budapest, 1999, 99. (ford. Rakovszky Zsuzsa et al.)

371 Uo. 109.

372 Uo. 109.

${ }^{373}$ Mindkét érv korszerü kifejtése és igényes kritikai tárgyalása megtalálható Brian Davies Bevezetés a vallásfilozófiába című könyvében, ezért ennél részletesebben nem kell kitérnünk a fentiekre.
} 
logikailag nem „kényszerítő erejü” bizonyításoknak tekinthetjük, hanem olyan argumentumoknak, melyek rámutatnak arra, hogy az Isten létébe vetett hit nem ésszerütlen. ${ }^{374}$

\section{c. Az antropikus elv a kortárs kozmológiában}

Az újkori gondolkodás kezdetét általában azzal a kopernikuszi fordulattal szokták jelölni, amelynek következtében az ember elveszítette kitüntetett kozmikus helyét, és a lakóhelyéül szolgáló, korábban mozdulatlannak tekintett Föld a Naprendszer bolygóinak egyikévé vált. A világegyetem dezantropocentrikus szemléletének tendenciája a modern gondolkodás, és az ennek középpontjában elhelyezkedő természettudományos megismeréseszmény talán legfontosabb jellegzetessége. A modern tudomány kitüntetett normája az a követelmény, amely szerint a világ leírásából ki kell kapcsolnunk az antropocentrikus és teleologikus elemeket, s ez szorosan összefügg azzal a meggyőződéssel, hogy a kozmosz rendje önmagáért való, és nem tekinthető az emberi létezésre irányuló, vagy egyéb célra irányított rendszernek.

Napjaink kozmológiájának belső fejlődése azonban új összefüggésben, újra felvetett néhány ide kapcsolódó kérdést. Az utóbbi évek kozmológiai publikációiban egyre gyakrabban találkozhatunk az úgynevezett antropikus kozmológiai elvvel, amely szerint, ha az ember térbeli elhelyezkedését tekintve nincs is kitüntetve, mélyebb és alapvetőbb értelemben mégiscsak privilegizált pozícióval rendelkezik a kozmosz rendjében. Hangsúlyoznunk kell, hogy itt nem a teleologikus világkép természettudományba való külsődleges visszacsempészésének egy újabb kísérletéről van szó, hanem olyan princípiumról, amelyet közvetlenül a fizikai kozmológiában fogalmaztak meg, és amely nélkül úgy tünik - legalábbis a kozmológusok jelentős része szerint -, hogy a természettudományos kozmológia nem boldogulhat. Annyi mindenesetre bizonyos, hogy az antropikus kozmológiai elv hosszú idő óta a legkomolyabb kihívás a dezantropocentrikus világleírással szemben.

Terjedelmi okokból a tudománytörténeti részleteket itt mellőznünk kell (ezekről Székely László részletes áttekintést ad). Rátérünk az antropikus elv Brandon Carter (1942-) és Stephen Hawking által az 1970-es évek elején adott meghatározásainak bemutatására. Jelen gondolatmenetünk szempontjából elegendő, ha az antropikus elvnek csupán két változatát különböztetjük meg:

1. Gyenge antropikus elv: elhelyezkedésünk a világegyetemben szükségképpen privilegizált - abban az értelemben, hogy összeegyeztethető megfigyelői minőségben való jelenlétünkkel.

2. Erös antropikus elv: a világegyetemnek - és így a fundamentális fizikai paramétereknek is, amelyektől az függ - olyannak kell lennie, hogy evolúciójának egy vagy több stádiumában lehetővé tegye magában megfigyelök kialakulását.

Az antropikus elv különböző változatai a standard modell nulladik pillanatnál megfigyelhető paraméterérzékenységére vonatkozó matematikai számítások és megfigyelések nyomán születtek meg. A fizika ma ismeretes törvényei alapján annak valószínűségére, hogy a kezdeti, forró univerzumból életre alkalmas világegyetem fejlődjön ki, a nullához igen közel álló értéket kapunk. Konkrétabban: ha fejlődésének korai szakaszában a világegyetem túl gyorsan tágult volna, a kozmikus anyag olyan hamar szétszóródott volna az expanzió során létrejövő kozmikus térben, hogy nem lett volna lehetőség kozmikus testek - sem galaxisok, sem csillagok, sem pedig bolygók - kialakulására; ha pedig túl lassú

${ }^{374}$ Vö. BAgYinSZKi P. ÁGoston: Az istenérvek hagyományáról, A Szív 102 (2016/3) 21-24. Az utóbbi időben nem véletlenül értékelődött fel a valószínüségi érvek szerepe az Isten léte melletti argumentációban. A terjedelmi korlátok miatt azonban ezek bemutatására itt nem vállalkozhatunk. Lásd pl. Richard Swinburne: Van Isten? Kossuth, Budapest, 1998. 
lett volna a kezdeti tágulás üteme, az általunk képviselt élethez szükséges csillagok szintén nem jöhettek volna létre, és a világegyetem hőmérséklete sem hült volna le annyira, hogy testünkhöz hasonló biológiai struktúrák fejlődhessenek ki benne. Az élet számára kedvező feltételeket biztosító kozmikus evolúciós pálya e „túl gyors” és „túl lassú” között helyezkedik el, mégpedig egy igen keskeny sávban. Így egyáltalán nem triviális, hogy az univerzum evolúciója során eljuthatott az élet számára kedvező stádiumba. A jelen állapot magyarázatához még be kell vezetnünk valamilyen posztulátumot - jobb híján erre látszik alkalmasnak az antropikus elv valamelyik változata, némi elméleti magyarázattal a háttérben.

Első látásra az antropikus elv körüli problematikát könnyü összekeverni a design-argumentum kérdéskörével. A teológusok és a természettudósok egyaránt el is szokták követni az azonosításnak ezt a hibáját. A lényeges különbség a következő: ha a standard modellben a jelenleg tetszőlegesnek választható, kezdeti paraméterek egy mélyebb törvény felfedezése által matematikailag levezethetőek lennének, ebben az új helyzetben az antropikus elv fölöslegessé válna, viszont a design-argumentum az új alaptörvénnyel kitűnő anyagot kapna a kozmosz tervezettségével operáló érvelés számára.

Ha azonban nem a természettudományos tudásunk fehér foltjaira vezethető vissza az antropikus princípium megjelenése, akkor mégis $\mathrm{mi}$ az igazi, mélyebb forrása ennek az elvnek? A tudományfilozófus válasza e kérdésre az, hogy ez a forrás a természettudományos világmagyarázat és a filozófia határvidékein található. Az antropikus kozmológiai elv kritikáját abban összegezhetjük, hogy természettudományos szintre húz le olyan problémákat, amelyek valójában csak a filozófia szintjén ragadhatók meg. A filozófia szintjén a természettudomány jövőbeli fejlődésétől függetlenül a következő dilemma rajzolódik ki számunkra: vagy nyitottak vagyunk valamiféle teleologikus világképre, vagy pedig az anyagban rejlő vak, de mégis az élet irányába mutató tendencia posztulálására van szükségünk a jelen magyarázatához. Korunk tudományának szelleme nem teszi valószínűvé a célszerüségi szemlélet (finalizmus) és az emberközpontúság (antropocentrizmus) egyidejü visszatérését. Ha a tudománytörténet belső logikája szerint majdan mégis újra be kéne vezetni ezeket, akkor bizonyára egy olyan kozmológiai modell szerint fog ez történni, amely valamilyen értelemben az ember létével is számot vet.

\section{A teremtettség és a dinamikus univerzum szembeállításának apóriája ${ }^{375}$}

Végül e negyedik részben arra teszünk kísérletet, hogy Karl Rahner gondolkodását követve bemutassuk, hogy ha van Isten és a világot Ö teremtette, akkor ez miként fogható fel plauzibilisen úgy, hogy összhangban legyen a fentebb tárgyalt fejlődő univerzum modelljével.

\section{a. A koncepció alapjai a görög és a középkori bölcseletben}

\section{Létezés és tevékenység}

Hétköznapi tapasztalatunk a világ dinamikus arcát tárja fel: a valóság folyamatos áramlásban van, az általunk észlelt dolgok állandó kölcsönhatásban vannak egymással. A hegyoldalról legördülő kő egy nyugalomban lévő sziklának adja át mozgási energiáját, a nap sugarai felmelegítik a levegőt. A dolgok természetes tevékenysége, az általuk a környezetükre kifejtett hatás (kauzalitás) alkotja a valóság dinamikus szövetét. Ehhez képest a világ és a dolgok létezése ritkán kerül érdeklődésünk

\footnotetext{
${ }^{375} \mathrm{Az}$,apória” itt használt jelentésének kifejtését lásd BAGYINSZKI P. ÁGOSTON - MÉSZÁROS LuKÁCS: Apóriák,
} avagy természettudomány és teológia párbeszédben, A Szív 102 (2016/9) 28-31. 
terébe, s ha igen, a létet hajlamosak vagyunk statikusan, dologi módon felfogni, mint ami egyfajta bináris logikában vagy létezik (1) vagy nem (0), ahogyan egy dolog a kezem ügyében jelen van, vagy éppen nincs. Ezzel szemben a középkor számos jeles gondolkodója (pl. Boethius, Aquinói Szent Tamás stb.) a létet nem főnévi, hanem igei természetűnek fogta fel (esse): a lét nem statikus meglét, hanem dinamizmus, s hogy a létezésnek ezt a sajátosságát megvilágítsák, előszeretettel fordultak az élet jelenségéhez: az élet az élőlény vonatkozásában olyan, mint a lét. ${ }^{376}$ Vagyis ahogyan az élet viszonyul az élőlény különféle élettevékenységeihez (táplálkozás, szaporodás stb.), úgy viszonyul a lét mozgalmassága a dolgok tevékenységeihez. Amint az organizmus minden tevékenységében az élet nyilvánul meg, úgy hatja át, nyilvánul meg a lét a létezők minden tevékenységében. Sem a lét, sem pedig a tevékenység (kauzális hatóképesség) nem dologi, statikus, hanem dinamikus valóság tehát, mindazonáltal a kettő nem esik teljesen egybe. Valami létezhet ugyanis anélkül, hogy a rá jellemző tevékenység(ek)et kifejtené (ahogy például a zenész létezhet anélkül is, hogy zenélne), ám semmi nem tevékenykedhet anélkül, hogy létezne. A létezés tehát a dolgok és tevékenységeik számára egyfajta conditio sine qua non, végső lehetöségi feltétel.

\section{A változás magyarázata}

Az előzőekben a valóság tevékeny, dinamikus voltára utaltunk. Arisztotelész éppen a valóságnak ezt a mozgalmas, folyvást változó voltát kívánta leírni. Eltekintett a változás egyedi, empirikus adottságaitól, és csak a változásban megmutatkozó formális, állandó struktúrák felé fordította figyelmét. Észrevette, hogy a változás mindig ellentétek közötti átmenetben valósul meg: valami nem$F$ a változás bekövetkeztével $F$ lesz (a nem fehér dolog fehérré válik, a nem mozgó dolog mozogni kezd etc.). Azt a valamit, ami a változás kiindulópontja (nem- $F$ jellegü dolgot) Arisztotelész anyagnak, míg a változás végpontját ( $F$ megjelenését) formának nevezte el. ${ }^{377} \mathrm{Az}$ anyag tehát a változás kiinduló-, a forma pedig annak végpontja. Ezért némi leegyszerúsítéssel azt mondhatjuk, hogy az anyag nem egyéb, mint az a lehetőség, amelyből és amelyen az új struktúra (forma), mintázat megjelenik. Ezzel azonban még nem tettünk egyebet, mint hogy általános, nem empirikus fogalmak segítségével írtuk le a változás empirikus, tapasztalati jelenségét. Leírtuk, de ezzel még nem magyaráztuk meg. Ezért találta Arisztotelész szükségesnek bevezetni az ok fogalmát is: a lehetőségből ugyanis önmagától nem jöhet létre az új struktúra, csak ha valami külső dolog hatást gyakorolva rá realizálja, aktualizálja az illető lehetőséget. Azt a külső ágenst, amely képes az anyag, azaz a lehetőség valóra váltására, oknak nevezzük. Az ok az, ami képiesen kifejezve mintegy „elővezeti” a formát az anyag - valamiképpen mindig előzetesen adott - lehetőségéből. Anyag, forma, ok az a három alapfogalom, melynek segítségével a mozgás és a változás metafizikailag megragadhatóvá válik.

\section{A teremtés apóriája}

A zsidó-keresztény hagyomány egyik sarokkövének számít a hittétel, hogy a világot Isten a semmiből teremtette. ${ }^{378} \mathrm{Ha}$ azonban a teremtés „szingularitását”, Isten levezethetetlen és semmi másra nem szoruló szabad tettét a görög metafizika keretei között kívánjuk interpretálni, úgy tűnik apóriába

376 „A lét másrészt magának a lényegnek az aktusát jelenti, ahogy az »élni«, amely az élök vonatkozásában a lét, a lélek aktusa. De nem második aktus, amely a tevékenység, hanem első aktus.” AQUINÓI SZENT TAMÁs: Scriptum Super Sententiis, lib. 1 d. 33 q. 1 a. 1 ad 1.

377 ARISZTOTELÉSZ: A természet, L’Harmattan, Budapest, 2010, 21-23. (ford. Bognár László)

${ }^{378}$ A hittétel teológiai értelmének mélyreható elemzését lásd PUSKÁs ATTILA: A teremtés teológiája, Szent István Társulat, Budapest, 2006. Körültekintő filozófiai, logikai rekonstrukcióját lásd GERÉBY GYÖRGY: A 'semmiböl teremtés' a skolasztikában, in FEHÉR MÁRTA (szerk.): A teremtés. Filozófiatörténeti tanulmányok, Áron Kiadó, Budapest, 1996. 9-89. 
jutunk. A teremtés ugyanis nem írható le a görög filozófia ill. az arisztotelészi metafizika hagyományos magyarázó elveivel. Nem mozgás, de nem is a változás egyéb neme (keletkezés), hiszen Isten a világot előzetesen adott anyag nélkül (a „semmiből”) hozta létre. A teremtés azt jelenti tehát, hogy Isten nem egyszerüen formát (struktúrát) adott az univerzum már meglévő anyagának a világ előzetesen adott lehetőségét valóra váltva, ${ }^{379}$ hanem az egész univerzum léte - annak minden téridőbeli lehetőségével együtt - tőle ered. A középkor keresztény gondolkodói világosan érzékelték e feszültséget saját hitük és a görög metafizika kategóriái között, és innovatív módon léptek túl azon. A teremtést olyan újszerü gondolatnak fogták fel, amely a görög filozófia csúcsának tekintett metafizikát saját, valódi mélységéhez juttatja. A metafizika ugyanis a saját maga által kitüzött programja szerint $a$ létet mint egészt és annak okait hivatott kutatni. A lehetőség (az anyag) azonban szintén létező valamilyen értelemben, így annak megléte is magyarázatra, egy végső okra szorul. A keresztény gondolkodók így Isten teremtő okságában az ok-fogalom metafizikai elmélyítésének, radikalizálásának lehetőségét látták. ${ }^{380}$

\section{A világ fenntartása}

Az ókortól kezdve a keresztény gondolkodók számára Isten az egyetemes (a létezés minden neméért felelős) ok, mely minden dolgot, minden előzetes feltételtől mentesen létrehívott. ${ }^{381} \mathrm{Ez}$ azonban további kiegészítést igényel. Isten ugyanis a teremtéskor nem úgy működött akár egy órásmester, aki létrehozta, kauzális szövetbe rendezte a világot, majd magára hagyta azt (deizmus), ellenkezőleg: folyamatosan fenntartja létében a világot, mivel enélkül a világ visszahullana a semmibe. Aquinói Szent Tamás Istennek ezt a folyamatos fenntartó tevékenységét ahhoz hasonlítja, ahogyan a Nap megvilágítja a levegőt: „Isten a dolgokat nem valamiféle újabb tevékenységgel tartja fenn, hanem létet adó tevékenységének folytatásával, amely mozgás és idő nélküli, ahogy a világosság megmarad a levegőben azáltal, hogy a Nap hatása folytatódik." 382 Ahogyan a Földön a Nap sugarai létrehozzák a nappalt és mindaddig amíg azok (megfelelő szögben) elérik a Földet nappal marad, úgy Isten létrehozta a világot, és ugyanezen aktussal létben is tartja azt. ${ }^{383}$ A teremtés és létbentartás tehát Tamás felfogásában a legszorosabban egybetartozik (az utóbbi nem más, mint az első aktus folytatása, continuatiója), ám a különbség mégis világos közöttük. A fenntartás a teremtő aktusra szorul: csak az tartható ugyanis fenn, ami már létezik. ${ }^{384}$ A sorok („mozgás és idő nélküli”) ${ }^{385}$ nyilvánvalóvá teszik, hogy az „első oknak” ez a létközlő-létbentartó tevékenysége nem értelmezhető a mozgás vagy a változás fentebb bemutatott hagyományos módján, vagyis nem ugyanaz a folyamat, ahogyan egy fizikai ok az anyag téridőbeli lehetőségeiből létrehoz egy, az ok természetével magyarázható okozatot.

379 A görögség hagyományos kérdése nem az volt, „miért van egyáltalán valami?”, hanem inkább az, „miért éppen ilyen az, ami van?".

380 Vö. például azzal, ahogyan Aquinói Szent Tamás a teremtés kapcsán kritizálja a platóni és arisztotelészi metafizikát. Summa Theologiae I. q. 44. a. 2; q. 45. a. 1.

381 A creatio ex nihilo tan talán első, részletesen kifejtett keresztény teológiai értelmezését már Antiochiai Szent Theophilosznál (†183) megtaláljuk. Lásd PUSKÁS ATTILA: i. m., 100-101.

382 AQUinói SzEnT TAMÁs: Summa Theologiae I. q. 104. a. 1. ad 4.

383 Szent Tamás felfogásának rövid összefoglalását lásd BRIAN DAVIES: The Thought of Thomas Aquinas, Clarendon Press, Oxford, 1993, 98-101.DOI: https://doi.org/10.1093/0198267533.001.0001

384 A két aktus különbségéhez lásd még BRIAN DAVIES: The Thought of Thomas Aquinas, 35. DOI: https://doi.org/10.1093/0198267533.001.0001

385 A kifejezéseket az indokolja, hogy a középkorban még nem tudták, hogy a fénynek is van sebessége. Arisztotelész nyomán úgy vélték, hogy a napfény instans módon, egyetlen pillanat alatt terjed szét a levegőben anélkül, hogy fizikai változást okozna abban. A jelenség tehát atipikus volta (a fizikai változás szokásos jeleinek hiánya) miatt mutatkozott alkalmas példának Szent Tamás számára az isteni kauzalitás bemutatásához. 


\section{Az isteni együttmüködés (concursus divinus)}

A teremtésnek ez a koncepciója további metafizikai lehetőségeket kínált Tamás számára, hogy Isten és a világ viszonyát érthetőbbé tegye. Ha ugyanis a teremtés és a fenntartás nem egyéb, mint létközlés, és a lét éppen az a hatás, amely minden egyes létezőben szükségképp jelen van, akkor Isten sajátos okozata, a lét révén minden dologban jelen van, éppen ezáltal képesítve az illető létezőt arra, hogy a rá jellemző tevékenységeket kifejtse, környezetére hatást gyakoroljon. De ugyanaz, ami a létező vonatkozásában lehetőség, hogy környezetére hasson, Isten vonatkozásában annak lehetősége, hogy a fizikai téridőbeli világban cselekvőként megnyilvánuljon, és a fizikai világ kauzális szövetét felhasználva hatásokat idézzen elő abban. ${ }^{386}$

A szemléletesség kedveért idézzük fel Jerikó történetét a Bibliából, és tegyük fel, hogy az ismert természeti törvények alapján van némi (meglehetősen csekély) statisztikai esélye annak, hogy ha a levegőben megfelelő hanghullámokat keltünk, azok a falakban rezonanciát okozva, meggyengítik az építmény szerkezetét. Istennek ekkor nem kell mintegy „varázsló módjára” kívülről, közvetlenül beavatkoznia a fizikai folyamatok szokásos lefolyásába, felülírva azok természetes müködését, hanem egyszerüen, mint transzcendens első ok, fenntartja a másodlagos okok sorát (kürtszó, levegő rezgése, a falak rezonanciája stb.) és e természetes ágensek természetes müködését kihasználva eléri voltaképpeni célját, Jerikó falainak leomlását. ${ }^{387}$ Röviden szólva tehát Isten a másodlagos okok természetes (és akár véletlenszerü!) ${ }^{388}$ összjátékát kihasználva képes kívánt okozatokat előidézni az univerzumban.

\section{b. A „kozmológiai apória” feloldásának egy lehetséges módja}

A középkor kozmológiai felfogása szerint a változás (keletkezés és pusztulás) és a fejlődés jelensége az univerzumnak csupán egy szükebb szeletére korlátozódik, a Hold pályája által bezárt térrészre, de valójában itt is az individuumokat, az egyes egyedeket érinti csupán. ${ }^{389}$ A középkortól idegen volt egy eredetileg egyszerübb, homogén állapotból a komplexitás állapota felé tartó, időben kibontakozó világegyetem gondolata, noha a szükséges bölcseleti elemek voltaképpen már készen álltak ennek metafizikai leírásához. A 20. században többek között a jezsuita Karl Rahner tett figyelemreméltó kísérletet arra, hogy a fejlődő világegyetem tudományos és a teremtő Isten keresztény elképzelése közötti összhangot megteremtse. ${ }^{390}$

${ }^{386}$ Szent Tamás az isteni együttmüködés gondolatát ezért a gondviselés problémája alatt tárgyalja. Ebből világos, hogy gondolkodásában a teremtés-fenntartás-gondviselés a legszorosabban összetartozik. Isten nem csupán létet adott a dolgoknak amikor azok létezésüket először megkezdték, hanem ameddig vannak, a létet folytonosan okozza bennük.

387 A másodlagos okok és az első ok együttmüködésének (hagyományos kifejezéssel concursus divinus) koncepcióját a középkor neoplatonikus közvetítéssel vette át (lásd a prokloszi ihletésü Liber de causis c. mü 3. propozícióját). Ez a koncepció többek között lehetővé tette a középkori gondolkodók számára, hogy a világban található esetlegesség, véletlen és a rossz problémájára magyarázatot találjanak, de ennek révén próbálták meg értelmezni az isteni kegyelem és a szabad akarat együttmüködését is. Tamás másodlagos okságra vonatkozó tanítását lásd ETIENNE GILSON: The Corporeal World and the Efficacy of Second Causes, in uő: The Christian Philosophy of St. Thomas Aquinas, University of Notre Dame Press, 1994, 174-186. DOI: https://doi.org/10.2307/2220319

388 Vö. AQUINÓI SZENT TAMÁs: Summa Theologiae I. q. 103. a. 5. ad 1.

389 A platóni-arisztotelészi kozmológiából átörökölt meggyőződésük szerint az élő és élettelen természetben megtalálható általános, faji jellegzetességek - amint a kozmosz többi része - lényegében változatlan formában állnak fenn a világ kezdete óta.

390 A jelenkori gondolkodásban a fentebb bemutatott tamási belátások inspirálták többek között a jezsuita csillagászt és teológust, W. Stoegert is. Vö. WiLliam R. StOEgER: Describing God's Action in the World in Light of Scientific Knowledge of Reality, in F. LERON SHULTS - NANCEY MURPHY - ROBERT J. RUSSELL 
Rahner egész metafizikai gondolkodásának középpontjában a tamási dinamikus létfogalom áll. A lét számára sem dologi, statikus, hanem a „semmi és a végtelen között oszcilláló” valóság. ${ }^{391}$ A létnek éppen ez a víziója vezette el a német gondolkodót egy olyan fejlődő univerzum gondolatához, mely lehetővé tette az emberi szellem megjelenését. ${ }^{392}$ Mivel ez a fejlődés az anyagtól az emberi szellem (továbbiakban: tudat) ${ }^{393}$ megjelenéséig ível, Rahner az antik-középkori anyag-forma fogalompárban keres alkalmas interpretációs eszközt, ${ }^{394}$ és ebben a fogalmi keretben veszi górcső alá, hogyan is kellene helyesen értenünk a klasszikus formulát, miszerint az ok egy új formát az anyag lehetőségéből „vezet elo"”.

Rahner kiindulópontjául a keletkezés problémája szolgál, és a skolasztikus formulát ennek esetein kívánja „vizsgáztatni”, azaz a változás olyan sajátos példáin, ahol ténylegesen valami minőségileg új jelenik meg a kiindulási állapothoz (anyag) és a keletkezést inicializáló ok természetéhez képest. ${ }^{395}$ Ezekben az esetekben ugyanis meggyőződése szerint a folyamat eredménye (a forma) nem vezethető le önmagában a kiinduló állapotból (az anyagból), mivel az anyag saját fogalma szerint nem egyéb, mint az új mintázat puszta lehetősége. Ha tehát olyan esettel állunk szemben, ahol a folyamat végén előálló struktúra minőségi újdonságot képvisel az okához képest, így abból nem vezethető le minden további nélkül - és Rahner ezt nevezi valódi keletkezésnek -, akkor a keletkezés magyarázatához egy olyan további okra kell hivatkoznunk, amely immár kívül áll a fizikai kauzalitás síkján. Rahner ezen a ponton eleveníti fel, és mélyíti el az isteni együttmüködés hagyományos gondolatát. ${ }^{396}$

\section{Az újfajta „teremtő” kauzalitás gondolata}

Rahner a keletkezés magyarázatát az isteni együttmüködés olyan koncepciójának kidolgozásától várja, mely képes számot adni arról, miként gondolható el az elsődleges ok és a másodlagos ok(ok) tevékenységének egysége. ${ }^{397}$ Vagyis lényegében a tamási koefficiensek gondolatához tér vissza, figyelemreméltó módon elmélyítve és kidolgozva az eredeti tamási koncepciót. Dialektikus, a felmerülő ellentétes szempontok egységét kereső megoldása a következő:

(eds.): Philosophy, Science and Divine Action, Brill, Leiden - Boston, 2009, 111-140. DOI: https://doi.org/10.1163/ej.9789004177871.i-446.26

391 KARL RAHNER: Geist in Welt, Kösel Verlag, München, 1957, 172.

392 A rahneri koncepció vázlatát annak teológiai (eszkatológiai) vonatkozásaival lásd PATRICK BURKE: Reinterpreting Rahner. A Critical Study of His Major Themes, Fordham UP, New York, 2002. DOI: https://doi.org/10.1017/s003693060635260x

393 Rahner a szellem (Geist) kifejezéssel az ember intellektuális, akarati és érzelmi életének határtalanságát jelöli. Arra a figyelemreméltó jelenségre utal, hogy az ember a lét egészére nyitott, „metafizikai lény”. Tudatában vagyunk, hogy e kifejezéshez képest a tudat fogalma első látásra szükebb, ám ha tekintetbe vesszük, hogy a Rahner által körvonalazott jelenség tudatos viszonyulás, ez a veszély elmúlik. A terminológiaváltást az indokolja, hogy a tudat fogalma (dacára sokértelmüségének) kezelhetőbb a jelenkori filozófiai és természettudományos nyelvhasználatban.

394 Az anyag-tudat rahneri értelmezéséhez lásd PAUL OVERHAGE - KARL RAHNER: i. m., 44-55; továbbá KARL RAHNER: Schriften zur Theologie, Band 6., Die Einheit von Geist und Materie im christlichen Glaubensverständnis, 185-214. DOI: https://doi.org/10.14315/evth-1957-jg35

395 PAUl OVERHAGE - KARL RAHNER: i. m., 63 skk. Vagyis Rahner szerint a „fejlődés” fogalmának megértéséhez a kulcsot nem a fizikai (helyváltoztató) mozgás vagy a mennyiségváltozás tanulmányozása szolgáltatja (Rahner szerint ezek leírására szorítkozik a fizika), hanem a keletkezés metafizikai fogalmának megértése.

${ }^{396}$ Hiszen ekkor az újdonság létét nem tudtuk racionálisan visszavezetni egy okra, így az mintegy a semmiből lépett elö, ezzel pedig megsértenénk az elégséges alap elvét. A rahneri szigorú értelemben vett keletkezés eseteit „emergenciának” is nevezhetjük. Rahner egyértelmüen ilyennek látja például a tudat és ezzel összefüggésben az individuális személy megjelenését a bioszférában Vö. PAUL OVERHAGE - KARL RAHNER: i. m., 81. Nem zárja ki továbbá, hogy a kozmoszban másutt is érvényesül hasonló „emergencia”, például az anorganikus és az organikus lét határán. Vö. uo. 82, 17-es számú lábjegyzet.

397 Uo. 68. 
„a végtelen ok, mely tiszta aktualitásként a valóság teljességét elözetesen magába foglalja, a véges ok 'felépitéséhez' ('in actu') anélkül tartozik hozzá, hogy ennek mint létezőnek a bensö mozzanata volna. E dialektikus állitás elsö fele által 'érthetővé' válik, hogy a véges ok valóban meg tudja haladni magát, éspedig saját magát. Azaz az általa létrehozott hatás (...) több mint ö maga, noha tôle magától ered. Tehát ö maga képes önmagát meghaladni. A második része ennek a dialektikus állitásnak érthetövé teszi, hogy e hatás valódi meghaladás lehet, amiröl nem lehetne szó, ha a véges ok felépitéséhez tartozó tiszta (végtelen) aktus a véges ok bensö mozzanata volna, mert ekkor ez már mindig birtokolná azt, amit magát meghaladva saját önfelülmúlásával (Selbsttranszendenz) kellene elérnie." ${ }^{\text {"398 }}$

Rahner egyrészt az isteni tevékenység immanenciáját állítja. Az isteni hatás a téridőbeli (másodlagos) ok saját, rá jellemző tevékenységében valamiképp jelen van, abban valósul meg, másként nem jelenhetne meg a téridö szövetében az új mintázat a természetes ok hatásának eredményeként. Másrészt a szakasz kifejezésre kívánja juttatni az isteni tevékenység transzcendens voltát is, ugyanis ezt az Istentől eredő hatást a téridőbeli létező nem saját természetének részeként birtokolja, vagyis hiába vizsgálnánk az illető fizikai ágens természetét, felépítését a legkülönfélébb módszerekkel, soha nem találnánk rá egy abban megbúvó rejtélyes isteni faktorra. Isten a másodlagos ok tevékenységében úgy tevékeny, hogy túl van azon (in-ihm-über-ihm). ${ }^{399}$ A félreértések elkerülése végett Rahner siet hangsúlyozni, hogy az isteni okság nem valamiféle „hézagpótlő” feltevés. Nem arról van szó, hogy egy a fizikai magyarázatok segítségével egyelőre még hiánytalanul ki nem töltött ürbe egy isteni okot ékelnénk közbe. A szerző újra és újra hangsúlyozza, hogy Isten nem tartozik a téridőbeli fizikai okok láncolatába sem úgy mint köztes elem, sem úgy mint első eleme a sornak. Újra emlékeztetni szeretnénk arra, hogy a teremtéstannal fellépő új kauzalitás-koncepció a metafizikai okság elmélyítéseként értelmezte magát, de maga a metafizikai értelmezésekben megjelenő okfogalom sem arra szolgál, hogy felváltsa, vagy alternatívája legyen egy fizikai magyarázatnak. Az említett területek között ugyanis perspektívaváltás történik: más és más a magyarázandó, és más az amivel magyarázunk. Amikor tehát Rahner arra hívja fel a figyelmet, hogy Isten nem egy a fizikai okok közül, azt akarja kifejezni, hogy a létezés és tevékenység más síkjához tartozik, mint a fizikai ágensek és kölcsönhatásaik horizontális szövete. Isten a világ alapja, nem pedig annak egy tényezője. Ahogy egy helyen tömören kifejezi: „Isten müködteti a világot és tulajdonképpen nem a világon belül müködik" ${ }^{400}$ Azaz Isten nem közvetlenül cselekszik a világban, hanem lehetővé teszi a másodlagos okok tevékenységét, és azt, hogy tevékenységük eredménye felülmúlja természetes hatóképességüket. ${ }^{401}$ Rahner azzal is igyekszik az isteni tevékenység transzcendens, nem téridőbeli voltát kifejezni, hogy eltávolítva a fizikai konnotációktól, erőszeretettel nevezi azt transzcendentálisnak. Olyan kifejezéssel él, amely nem fizikai, de eredendően nem is ontológiai, hanem ismeretelméleti jellegü, s amelynek eredetét a kanti filozófiában találjuk. Kantnál a kifejezés egyfajta beállítódásváltást, a figyelem átállítását jelentette. Nem azt kutatjuk, ugyanis, hogy micsoda egy adott dolog, hanem arra kérdezünk rá, hogy mi teszi lehetővé azt, hogy az illető dolgot megismerhessem. Rahner számára egyrészt azért tủnt alkalmasnak a kifejezés, mert egyfajta távolságvételt, perspektívát tett lehetővé az empirikus, fizikai összefüggésekkel szemben, ezzel képes volt aláhúzni Isten transzcendenciáját a világhoz képest. Másrészt a terminus az egész rahneri filozófia

\footnotetext{
${ }^{398}$ Uo. 69.

${ }^{399}$ Uo. 73.

${ }^{400}$ Rahnert idézi Reinhold Bernhardt, in uő: „Was heißt Handeln Gottes”? Eine Rekonstruktion der Lehre von der Vorsehung, Gütersloh, Gütersloher Verlag, 1997, 387.

${ }^{401}$ Uo. 389.
} 
indíttatását is jelzi: az ontológiai és metafizikai alapfogalmak jelentése a német jezsuita szerint ugyanis csak az emberi szubjektivitás, a tudat elemzésének segítségével világíthatóak meg kielégítően.

Tudat és anyag együttmüködésének lehetösége a megismerésben

Ezen a ponton válik világossá a rahneri módszer újszerüsége az egész problematika hagyományos megközelítéséhez képest. Amikor ugyanis nekifog az anyag és a tudat viszonyának tisztázásához, igazolja, hogy a helyes módszer az, ha eleve, ab ovo a tudatból indulunk ki. Egyébként sem tehetünk mást - mondhatnánk -, hisz az ember az anyagi világ törvényszerüségeit kétségtelenül a saját megismerőképességét használva tárja fel. Továbbá egyszerủen nem vonatkoztathatunk el attól a ténytől, hogy a kozmosz törvényei és fejlődése lehetővé tette a tudat megjelenését. ${ }^{402}$ Ám egy további nyomós érve is van a szerzőnek. Minden összezavarodik ugyanis, ha az anyaggal kezdjük a vizsgálódásainkat, mondván, a világban mindenütt anyagi dolgok vesznek körül minket, így az anyag természete ismert számunkra, míg a tudat megismeréséhez csak nagy nehézségek árán juthatunk el. Rahner szerint ebből a hibás elöítéletből adódnak a problémák, hogy a tudat természetét megpróbáljuk magától értetődően levezetni az anyag fizikai müködéséből. A dolog ugyanis éppen fordítva áll. Arról, hogy mi a tudat, világos tapasztalatunk van, pillanatról pillanatra tapasztaljuk a müködését önmagunkban. ${ }^{403}$ Rahner e módszertant követve tesz kísérletet arra, hogy az általa használt metafizikai alapfogalmakat a tudat tapasztalatából vezesse le.

Az isteni együttmüködés elfogadásának egyik gátját az jelentheti, hogy nehéz elgondolnunk két látszólag radikálisan különböző természet, a tudatos szellem (Isten) és az anyag (kozmosz) viszonyát. Pedig a tudat és az anyag együttmüködése egyáltalán nem valamiféle „miszticizmus”, saját megismerésünk müködésén tanulmányozható ugyanis. Amikor egy téridőbeli materiális létezőt megismerünk, az annak köszönhető, hogy az illető dolog kauzális hatást gyakorol ránk (érzékszerveinken keresztül). Ám a tárgy tudatosodását aligha írhatjuk le úgy, mint valamiféle fizikai hatást, amely mintegy „belegravírozza” magát a tudatba. Ugyanis nem maga a fizikai hatás valósul meg a tudatunkban, hanem a tudat saját tevékenységének és a fizikai tárgy fizikai tevékenységének az együttes hatása. Ezt nevezzük a tárgyról való ismeretnek, és ez az ismeret valódi önfelülmúlást mutat a fizikai dologhoz képest: képes megjeleníteni a dolog fizikai jellemzőit, és egyben a tudat sajátosságait is hordozza. Ez az új összefüggés nem vezethető le maradéktalanul a tárgy téridőbeli, fizikai jellegzetességeiböl, ugyanis megjelenésének lehetőségi feltétele a tudat müködése. De Rahner szerint az öntranszcendencia eredeti paradigmáját, valódi tapasztalatát szellemünk létre való nyitottságában találjuk meg.

A német jezsuita műveiben újra és újra megkísérel számot adni a mindannyiunk által jól ismert jelenségről, miszerint megismerésünk bizonyos határtalanságot mutat. Ennek jele az ember nyughatatlan felfedezési vágya, a valóságra való vég nélküli rákérdezés, a „miértek” meg nem szünő sora. Az ember nem képes megmaradni a véges összefüggéseknél, hanem folytonosan a határtalant, a végtelent ostromolja. Sőt éppen a tudat határtalansága, az egész lét felé való nyitottsága teszi lehetővé, hogy egyáltalán „,világról” beszélhessünk, s egy véges objektumot a világon belüliként, világunk részeként határoljunk körül, tudatosítsunk. Ugyanez a dinamizmus visszhangzik akarati életünkben és a szeretet jellegzetességeiben is. Rahner szerint az emberi tudat nyitottságának egyfajta „iránya” (Woraufhin) van, amennyiben a számunkra mindig csak horizontszerüen adódó végtelen isteni lét az, amely a tudatnak ezt a benső mozgását, dinamizmusát konstituálja, lehetővé teszi. Rahner ebben látja azt a fenomént, mely meggyőződése szerint tökéletesen érthetővé teszi az önfelülmúlás jelenségét. A tudat határtalanságának lehetőségi feltétele ugyanis éppen ez a végső horizont, amely nem mozzanata a tudatnak, nem tartozik magához a tudatnak a „szerkezetéhez”, hanem túl van rajta, és éppen mivel

402 Lásd fentebb a tanulmány 3/c pontját.

403 Vö. PAUl OVERHAGE - KARL RAHNER: i. m., 44-55. 
túl van rajta, képes mozgásba lendíteni a tudat dinamizmusát. Ebben az értelemben, egyfajta transzcendentális feltételként mégis valamiképp ,jelen van számára”, lehetővé téve az ember önfelülmúlását, hogy az emberi tudat folyvást túllépjen minden véges, fogalmilag megragadható adottságon. ${ }^{404}$

\section{Az új kauzalitásfogalom kiterjesztése}

Az önfelülmúlás fogalmának bevezetésénél említettük, hogy Rahner számára a keletkezés vizsgálata szolgált kiindulópontul ahhoz, hogy eljusson az önfelülmúlás és az isteni együttmúködés összefüggéséig. Vagyis a „teremtő kauzalitás” újfajta fogalma az önfelülmúlás jelenségével korrelációban került kifejtésre. Ám az önfelülmúlás kapcsán Rahner voltaképpen egyedül a tudat valóságát elemzi. Eszerint az isteni együttmüködés kapcsán kidolgozott újszerü ok-fogalomnak egyedül a tudatélet elemzésekor vennénk hasznát, míg az anorganikus kozmosz egész világa kívül reked az első ok „teremtő okságának” hatókörén? Rahner az általa kidolgozott ok koncepciót kiterjeszti az egész valóságra. Az önfelülmúlás kapcsán bemutatott kauzalitást ugyanis „ontológiai ősparadigmának" (ontologische Urparadigma) tekinti, azaz minden (organikus és anorganikus) kauzális hatás modelljének tekinti, ${ }^{405}$ amennyiben az univerzumunkban előforduló bármely, fizikai síkon kimerítően magyarázható kauzalitás valójában ennek a paradigmának a deficiens módozata, nem mintaszerü, nem teljes megvalósulása. ${ }^{406}$ Az önfelülmúlás tehát olyan jelenség az univerzumban, amely a lehetséges maximuma (a tudat megjelenése) és minimuma (az anorganikus szférában megmutatkozó mindenféle „,ugrást” nélkülöző átmenetek) között „oszcillál”. Ám függetlenül attól, hogy a természetben megmutatkozik-e bármiféle „minőségi ugrás”, vagy az anorganikus szférát puszta mennyiségi átmenetek töltik ki, Isten transzcendentális, a világot fenntartó oksági hatása teszi lehetővé, hogy a kauzalitás téridőbeli szövete fennmaradjon.

\section{c. Rövid összegzés}

Amennyiben a fizikai kozmológia standard paradigmájára a Karl Rahner által megnyitott perspektívából tekintünk rá, a következö összegzést adhatjuk. A valóság legalapvetőbb, legmélyebb rétege (a lét) nem dologi jellegü, hanem dinamikus, oszcilláló adottság, ebböl következően világunk téridőbeli elemei maguk is folytonos „fluxusban”, alakváltozásban vannak. A bevett kozmológiai modell alapján egy fejlődő, „evolutív” világegyetem képe rajzolódik ki előttünk, amennyiben a fejlődés során az időben később megjelenő komplexebb mintázatok folyvást felváltják a korábbiakat. Az anyag kezdeti lehetőségeiből az ősrobbanással kialakultak az elemi részecskék, majd az egyre összetettebb struktúrák, galaxisok és galaxishalmazok, létrejött univerzumunk ma megfigyelhető komplex rendszere. Az emberi tudat maga is ennek az anyagnak a lehetőségeiből bontakozott ki, így az univerzum fejlődésétől nem elszigetelhető jelenség, hanem annak része. Mégsem tekinthetünk el kitüntetett voltától. Ugyanis paradox módon, miközben létrejötte része e történetnek, maga ez a történet ugyanennek a tudatnak a „része”. Mindaz ugyanis, amit a fizika törvényeiről és a világról tudunk, a tudatnak a tartalma, s az hogy egyáltalán a „világegész” fogalmával rendelkezzünk a tudat határtalanságának következménye. A tudat tehát úgy „része” a kozmosz történetének, hogy lényegileg meg is haladja e történet kvantitatív, téridőbeli meghatározottságait, így nem vezethető le minden

\footnotetext{
404 Vö. uo. 70-74.

405 Uo. $74-75$.

406 Uo. 74.
} 
további nélkül azokból. Karl Rahner szerint ez az „önfelülmúlás” magyarázatra szorul, és keresztény gondolkodóként ezt a magyarázatot az első ok teremtői okságában keresi.

A tudat kiemelkedése annak az általános kauzalitásnak egy figyelemreméltó esete, ahogyan Isten együttmüködik a világgal, fenntartva a fizikai okok sorát és képesíti azokat természetes okozataik létrehozására anélkül, hogy maga e téridőbeli kauzális szövet egyik eleme volna. A Nagy Bumm kiindulópontjául szolgáló tiszta lehetőség (az ősrobbanás alapját képező „,anyag”) maga is a teremto okság eredménye, ahogyan az anyag minden további új mintázata egészen a tudat kifejlődéséig a már létező fizikai adottságok és a teremtő ok folyamatos és együttes hatásának eredményei, ám másként és másként. Isten a másodlagos okok kauzális tevékenységét lehetővé tevő alap, végső lehetőségi feltétel, s mint ilyen kívül esik az általa lehetővé tett téridőben megnyilvánuló oksági sor szövetén. A „teremtő ok" mindazonáltal nem mássá teszi a másodlagos okokat működésük közben, hanem hozzásegíti őket ahhoz, hogy saját természetes működésüket kifejtsék, kiteljesítsék. E természetes, téridőbeli müködés tanulmányozása a fizika és a fizikai kozmológia feladata. A fentebb körvonalazott metafizikai koncepciónak megvan az az előnye, hogy támogatja a természettudományos kutatás önállóságát, elismeri eredményeit, módszereit. Saját kutatási területét nem a természettudományokkal való szembenállás és vita révén nyeri el, hanem azzal, hogy nem áll meg a fizikai, téridőbeli létezés határainál (így pl. az ősrobbanás tényénél), hanem a kauzalitás fogalmának radikalizálása révén egy végső értelmesség irányában mélyíti el a kérdezés lehetőségét. Ezt a lehetőséget kétségkívül a vallás élteti. De nem ugyanez a vallási tapasztalat felelős-e azokért az alapfogalmakért is, melyek nélkül egyáltalán nem volna lehetséges a kozmosz eredetére való rákérdezés? 
